\title{
The Estimation of Corrosion Behavior of NiTi and NiTiNb Alloys Using Dynamic Electrochemical Impedance Spectroscopy
}

\author{
Georgiana Bolat, ${ }^{1}$ Daniel Mareci, ${ }^{1}$ Sorin Iacoban, ${ }^{2}$ \\ Nicanor Cimpoesu, ${ }^{3}$ and Corneliu Munteanu ${ }^{2}$ \\ ${ }^{1}$ Faculty of Chemical Engineering and Environmental Protection, "Gheorghe Asachi" Technical University of Iasi, \\ 73 Professor Dr. Doc. D. Mangeron Boulevard, 700050 Iasi, Romania \\ ${ }^{2}$ Faculty of Mechanical Engineering, "Gheorghe Asachi" Technical University of Iasi, 61-63 Professor Dr. Doc. D. Mangeron Boulevard, \\ 700050 Iasi, Romania \\ ${ }^{3}$ Faculty of Materials Science and Engineering, "Gheorghe Asachi" Technical University of Iasi, 61A Professor Dr. Doc. D. Mangeron \\ Boulevard, 700050 Iasi, Romania \\ Correspondence should be addressed to Daniel Mareci; danmareci@yahoo.com
}

Received 14 June 2012; Accepted 13 September 2012

Academic Editor: Maciej Sitarz

Copyright (C) 2013 Georgiana Bolat et al. This is an open access article distributed under the Creative Commons Attribution License, which permits unrestricted use, distribution, and reproduction in any medium, provided the original work is properly cited.

\begin{abstract}
Linear anodic potentiodynamic polarization and dynamic electrochemical impedance spectroscopic (DEIS) measurements were carried out for $\mathrm{NiTi}$ and $\mathrm{NiTiNb}$ alloys in physiological $0.9 \mathrm{wt} \% \mathrm{NaCl}$ solution in order to assess their corrosion resistance. DEIS measurements were performed from open circuit potential to dissolution potential. It was shown that the impedance measurements in potentiodynamic conditions allow simultaneous investigation of changes in passive layer structure. The impedance spectra of various potential regions were fitted and also discussed. The surface morphology of the alloys after linear anodic polarization test was studied using scanning electron microscopy (SEM) technique.
\end{abstract}

\section{Introduction}

Ti and its alloys have become one of the most attractive biomaterials due to their better corrosion resistance, biocompatibility, good fracture toughness, and relatively low modulus [1-4].

NiTi alloy has become important biomedical materials used in orthopaedic, cardiovascular, urological surgery, and orthodontics [5-9] due to its mechanical (shape memory and superelasticity) and corrosion resistance properties and good biocompatibility [10-12].

Nevertheless, a major concern on the dissolution properties of NiTi alloy still remains owing to the high nickel content; nickel science has been shown to determine several adverse biological effects $[13,14]$.

Usually, NiTi alloys present a superficial thin layer with $\mathrm{TiO}_{2}$ as the main component [15] protecting them from dissolution, as for commercial pure titanium [16].
The potential of this passive film breakdown is, sometimes very low for NiTi alloys, leading to active dissolution processes. Third alloying element was added to NiTi alloy to enhance its mechanical or corrosion properties. NiTiNb alloys have been developed recently as potential orthodontic arch wire materials; unfortunately little published works can be found so far as concerning the corrosion resistance of these alloys in physiological solution [17].

The electrochemical impedance spectroscopy (EIS) is an important technique for the examinations of passive layer. In the classical EIS technique the system can be considered as a stationary one, in which case the investigated process should remain constant during the time of full impedance experiment. Dynamic electrochemical impedance spectroscopy (DEIS) is a method of impedance measurements and creates a new possibility of corrosion investigation. In this method, impedance spectra are determined under potentiodynamic conditions (nonstationary condition). 
In the present work, the dynamic electrochemical impedance spectroscopy (DEIS) measurements were carried out to investigate the passive film behavior under linear potential change for $\mathrm{NiTi}$ and $\mathrm{NiTiNb}$ alloys.

\section{Materials}

A NiTiNb alloy produced by National Institute of Research and Development for Non-ferrous and Rare Metals, Bucharest, Romania, was used for the study; it had the following chemical composition ( $\%$ by weight): $\mathrm{Ti}=37.8, \mathrm{Nb}$ $=14.5$, and $\mathrm{Ni}=$ balance. An equiatomic NiTi alloy produced by the same supplier was used in some tests as a reference material. Both alloys were synthesized by electron beam melting technique.

The samples were cut into $0.21 \mathrm{~cm}^{2}$ sizes, and brass nut was attached to the sample using conductive paint to ensure electrical conductivity. The assembly was then embedded into an epoxy resin disk [18].

Then the samples were grounded with $\mathrm{SiC}$ abrasive paper up to 2000 grit; final polishing was done with $1 \mu \mathrm{m}$ alumina suspension. The samples were degreased with ethyl alcohol followed by ultrasonic cleaning with deionised water and dried under an air stream.

Electrochemical corrosion tests were performed for both samples in aerated physiological $0.9 \mathrm{wt} \% \mathrm{NaCl}$ solution (B. Braun Melsungen AG, Germany). The $\mathrm{pH}$ of this solution was 6.9 .

2.1. Electrochemical Measurements. Electrochemical measurements were carried out in $0.9 \mathrm{wt} \% \mathrm{NaCl}$ solution at $37^{\circ} \mathrm{C}$ using a Princeton Applied Research potentiostat (Model 263 A) connected with a Princeton Applied Research 5210 lock-in amplifier controlled by a personal computer and a specific software package called Electrochemistry Power Suite (Princeton Applied Research). A glass corrosion cell kit with a platinum counter-electrode and a saturated calomel reference electrode (SCE) was used to perform the electrochemical measurements. All potentials referred to in this paper are with respect to SCE.

After the open circuit potential (OCP) was held for 1 hour, the linear anodic polarization test was performed in $0.9 \mathrm{wt} \% \mathrm{NaCl}$ solution at a sweep rate of $1 \mathrm{mV} / \mathrm{s}$, from OCP to $500 \mathrm{mV}$.

Dynamic electrochemical impedance spectra (DEIS) were acquired from the open circuit potential to the dissolution region with a step potential of $20 \mathrm{mV}$ in the frequency range of $50 \mathrm{kHz}-0.01 \mathrm{~Hz}$ with a $10 \mathrm{mV}$ amplitude sine wave.

In order to supply quantitative support for discussioning the experimental impedance spectra results, an appropriate model (ZSimpWin-PAR, USA) for equivalent circuit (EC) quantification has also been used. The usual guidelines for the selection of the best-fit EC were followed: a minimum number of circuit elements are employed, the $\chi^{2}$ error was suitably low $\left(\chi^{2}<10^{-4}\right)$, and the error associated with each element was up to $5 \%$. Instead of pure capacitors, constant phase elements (CPEs) were introduced in the fitting

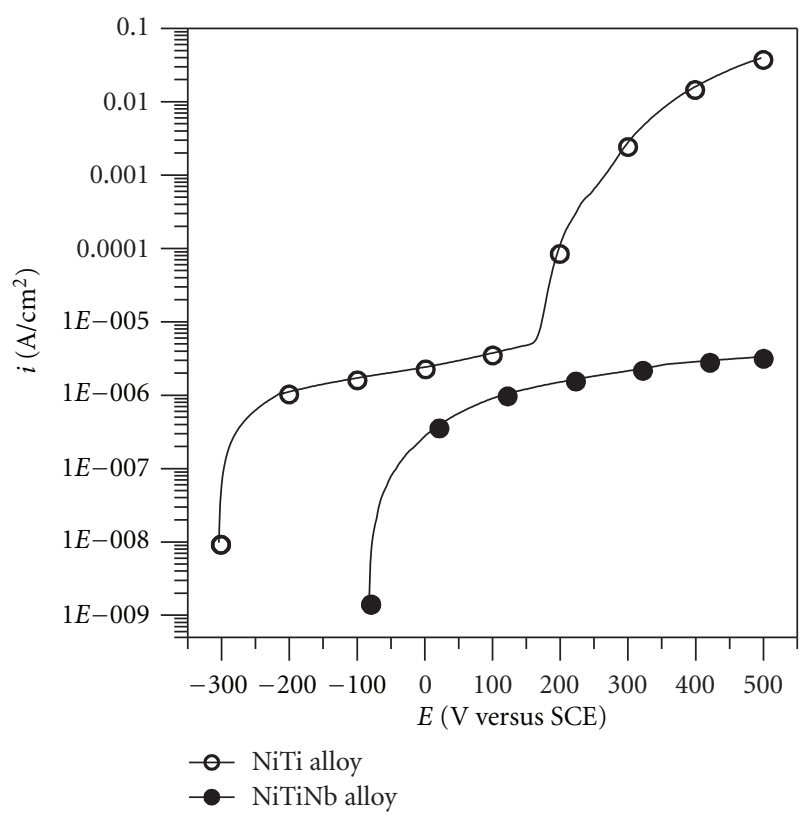

FIGURE 1: Linear anodic potentiodynamic polarization curves measured for NiTi and NiTiNb alloys after immersion in physiological $0.9 \mathrm{wt} \% \mathrm{NaCl}$ solution.

procedure to obtain good agreement between the simulated and experimental data.

2.2. Scanning Electron Microscopy of Corroded Surfaces. To observe the surface morphology of the alloys after linear anodic potentiodynamic polarization test, the specimens were ultrasonically cleaned in deionized water, dried under an air stream, and then examined by a scanning electron microscopy (SEM). To perform this Vega Tescan, scanning electron microscope (model VEGA II LMH) was used.

\section{Results and Discussion}

Plots in semilogarithmic scale of current densities corresponding to NiTi samples in aerated physiological $0.9 \mathrm{wt} \%$ $\mathrm{NaCl}$ solution at $37^{\circ} \mathrm{C}$ traced between open circuit potential to $500 \mathrm{mV}$ with $1 \mathrm{mV} / \mathrm{s}$ potential sweep rate are displayed in Figure 1. Prior to the beginning of the linear anodic polarization procedures, the samples were kept in the solution for 1 hour.

The nature of the linear anodic potentiodynamic polarization curves indicated that both samples have been passivated immediately after the immersion in physiological $0.9 \mathrm{wt} \% \mathrm{NaCl}$ solution. These samples translated directly from the "Tafel region" into a stable passive state, without exhibiting an active-passive transition. The addition of $\mathrm{Nb}$ on NiTi alloy shifted to the positive (noble) direction the anodic polarization curve. Figure 1 clearly proves that NiTiNb alloy had a better corrosion resistance than that of NiTi alloy, and this results in smaller values for the passive current densities $\left(i_{\text {pass }}\right)$. Passive current density was determined from the linear anodic potentiodynamic polarization curve and is obtained 


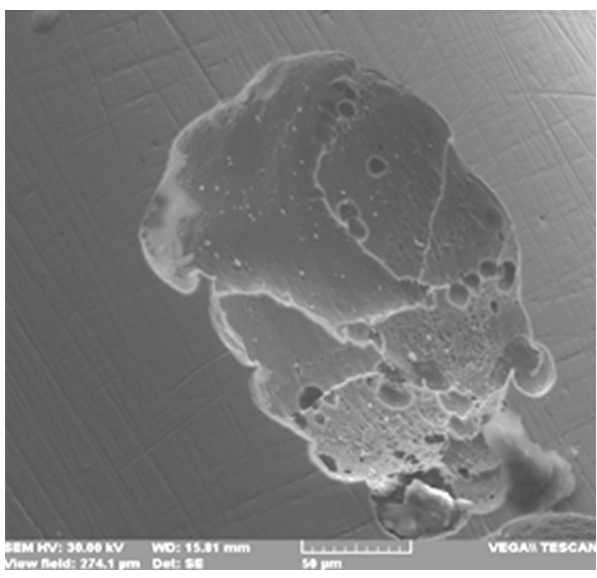

(a)

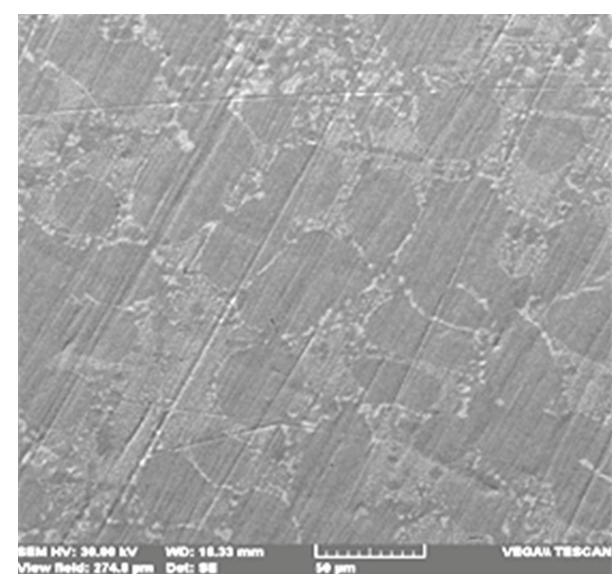

(b)

FIGURE 2: SEM images of corroded surfaces on (a) NiTi and (b) NiTiNb alloys after anodic potentiodynamic polarization tests.

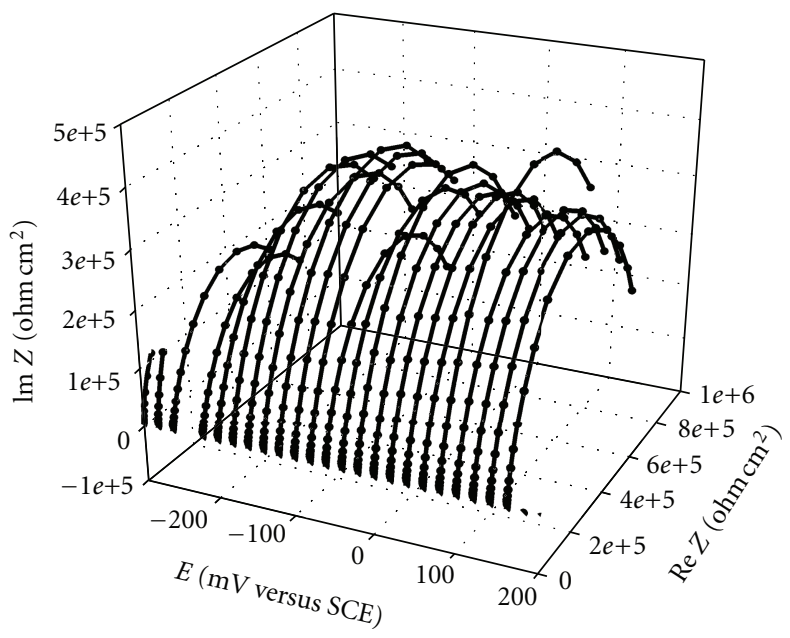

(a)

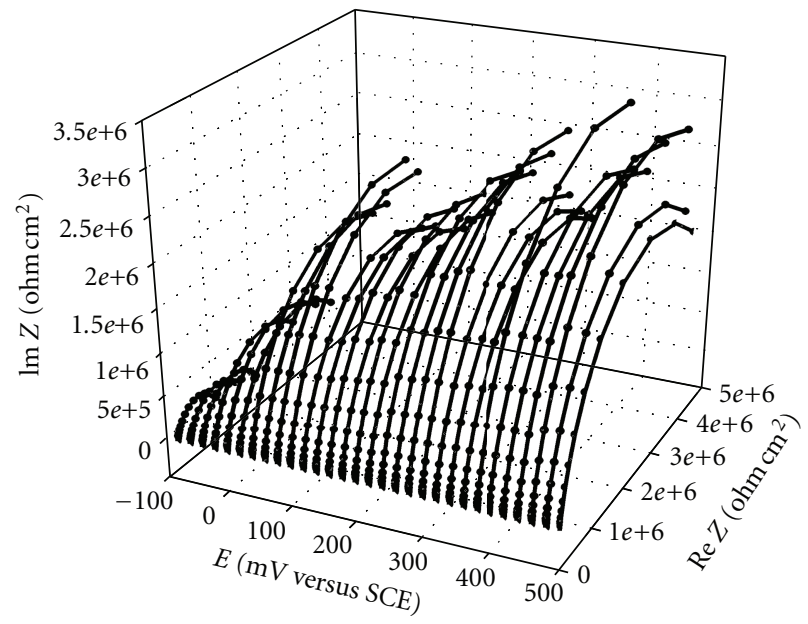

(b)

FIgURE 3: The impedance versus potential diagram of (a) NiTi and (b) NiTiNb alloys.

TABLE 1: The mean values of corrosion parameters measured for both samples in physiological $0.9 \mathrm{wt} \% \mathrm{NaCl}$ solution.

\begin{tabular}{lcc}
\hline Samples & $i_{\text {pass }}\left(\mu \mathrm{A} / \mathrm{cm}^{2}\right)$ & $E_{\mathrm{bd}}(\mathrm{mV})$ \\
\hline NiTi alloy & 2.5 & 170 \\
NiTiNb alloy & 1.1 & - \\
\hline
\end{tabular}

around the middle of the passive range. Table 1 lists the mean values of corrosion parameters measured for the $\mathrm{NiTi}$ and $\mathrm{NiTiNb}$ alloys in physiological $0.9 \mathrm{wt} \% \mathrm{NaCl}$ solution.

In the case of NiTiNb alloy from open circuit potential up to $-50 \mathrm{mV}$, anodic curve indicates typical behaviour of activation polarization. From $-50 \mathrm{mV}$ up to $500 \mathrm{mV}$ the curve shows a passive behaviour. In contrast with the $\mathrm{NiTiNb}$ sample, the NiTi alloy exhibited a breakdown in $0.9 \mathrm{wt} \% \mathrm{NaCl}$ solution. On anodic polarization from open circuit potential, an initial passive region was observed prior to current increase, which is associated with breakdown potential $\left(E_{\mathrm{bd}}\right)$ for localized corrosion. Breakdown is evident from the sharp increase in anodic current around $170 \mathrm{mV}$.

Within the human body, commercial pure titanium (Cp-Ti) may be subjected to potentials of up to $500 \mathrm{mV}$ [13].

Unfortunately, the same information has not been found for NiTi and NiTiNb alloys. By comparing the $E_{\mathrm{bd}}$ value of $\mathrm{NiTi}$ alloy recorded in this work with the potential for $\mathrm{Cp}-\mathrm{Ti}$ $(500 \mathrm{mV})$, we can conclude that appreciable attention should be given to the passivation of NiTi alloy.

The corroded surfaces of both alloys were observed by means of scanning electron microscopy (SEM). SEM images, Figures 2(a) and 2(b), were obtained after anodic potentiodynamic polarization tests of both samples. The SEM images analysis indicated a different behavior of NiTINb alloy in comparison with the NiTi alloy characterized by pitting corrosion. When the NiTiNb alloy was polarized up to $500 \mathrm{mV}$, the dendritic morphology can be observed. The 


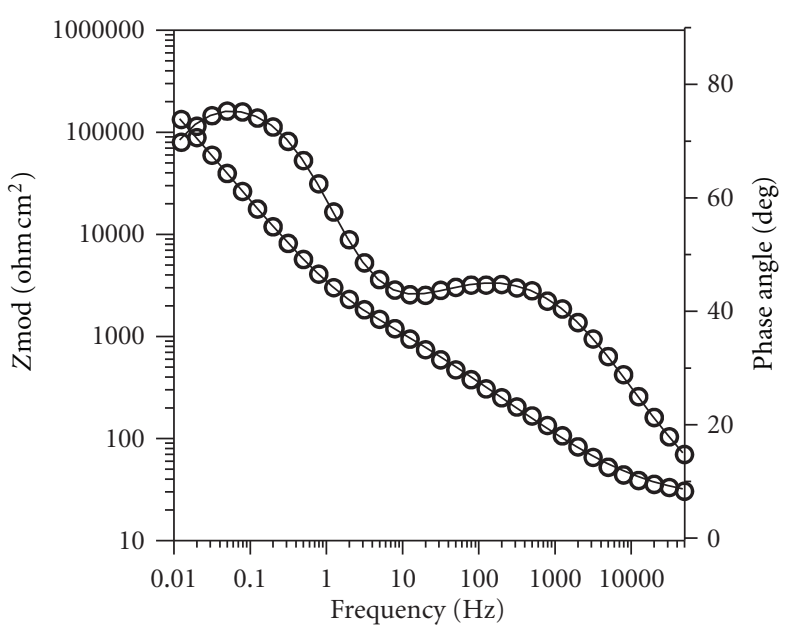

(a)

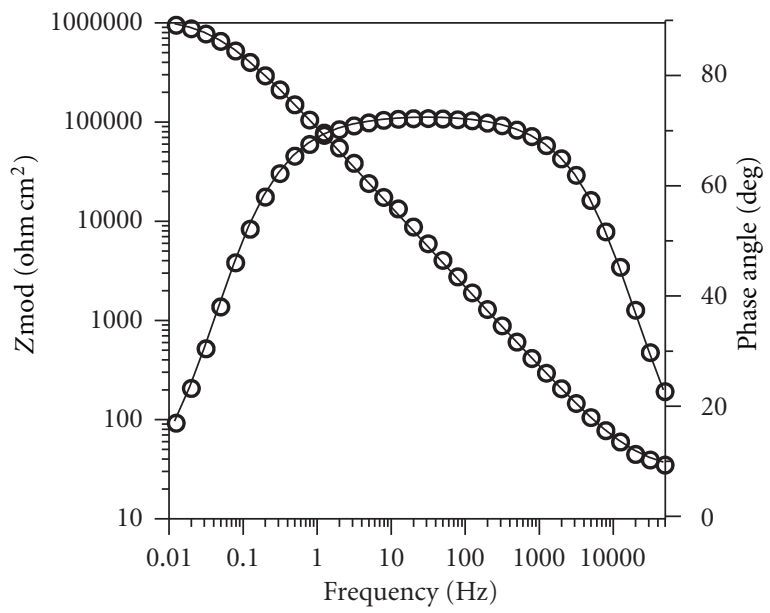

(b)

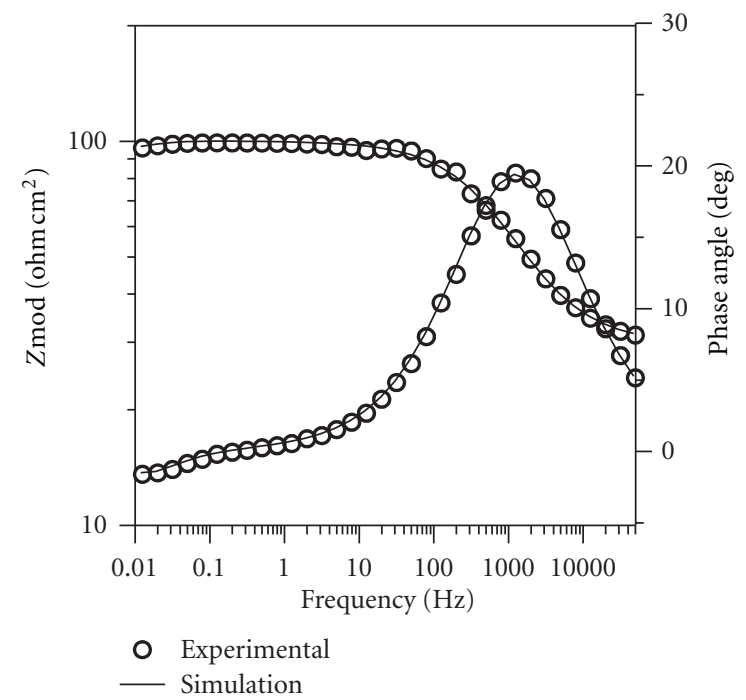

(c)

FIGURE 4: Bode plots for EIS data of NiTi alloy at (a) open circuit potential, (b) passive region, and (c) dissolution region.

role that $\mathrm{Nb}$ plays as an alloying element is by increasing the resistance of NiTi alloy to pitting corrosion.

The impedance spectroscopic analyses were carried out on both samples for every $20 \mathrm{mV}$ increase in the potential, beginning from OCP to the dissolution potential for NiTi alloy or to the $500 \mathrm{mV}$ for NiTiNb alloy. Figures 3(a) and 3(b) depict a three-dimensional representation of the resulting impedance spectra of NiTi and NiTiNb alloys. From Figure 3, a successive change in the shape of each impedance spectrum with increase in potential was observed for both alloys.

In order to have a better understanding of the corrosion process, electrochemical impedance spectra at a potential in each region, namely, OCP, passive, and dissolution were selected from the potentiodynamic impedance spectra.

From the potentiodynamic impedance spectra three potentials were selected for NiTi alloy: OCP, $-30 \mathrm{mV}$ (passive region), and $200 \mathrm{mV}$ (dissolution region), and the corresponding Bode plots are presented in Figures $4(\mathrm{a})-4(\mathrm{c})$. The advantage of the Bode plot is that the data for all measured frequencies are shown and that a wide range of impedance values can be displayed.

The Bode-phase plots for NiTi alloy at OCP show two relaxation constants, that is, two peaks are observed in the Bode-phase plots. A proposed equivalent circuit (EC) for the electrochemical interface may be seen in Figure 5(a). The EC is characterized by two parallel combination terms (RQ) in series with the resistance of the solution $\left(R_{\text {sol }}\right)$. The two RQ elements can be attributed to charge transfer and separation processes at the alloy/oxide layer interface $\left(R_{1} Q_{1}\right)$ and to the oxide layer formed on the surface $\left(R_{2} Q_{2}\right)$. Large values of $R_{2}$, at OCP (order $10^{5} \Omega \mathrm{cm}^{2}$ ), were obtained confirming the formation of a passive oxide layer with good corrosion protection ability. As the potential changes from OCP to $-30 \mathrm{mV}$ (passive region), the Bode-phase plots are in agreement with an EC with one time constant (Figure 5(b)). The EC consists of the parallel combination terms $\left(R_{2} Q_{2}\right)$ in series 


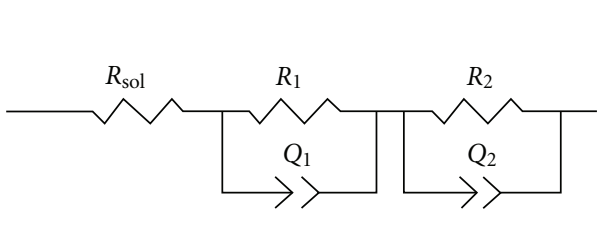

(a)

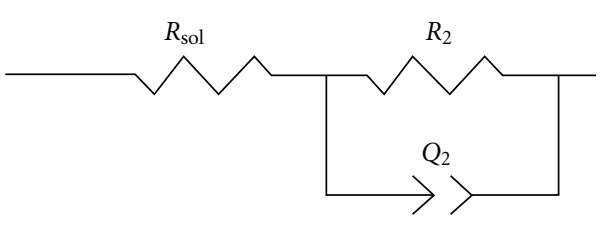

(b)

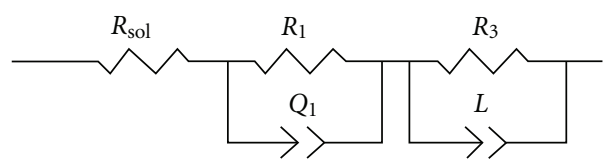

(c)

FIGURE 5: Equivalent circuits used for fitting the measured impedance spectra.

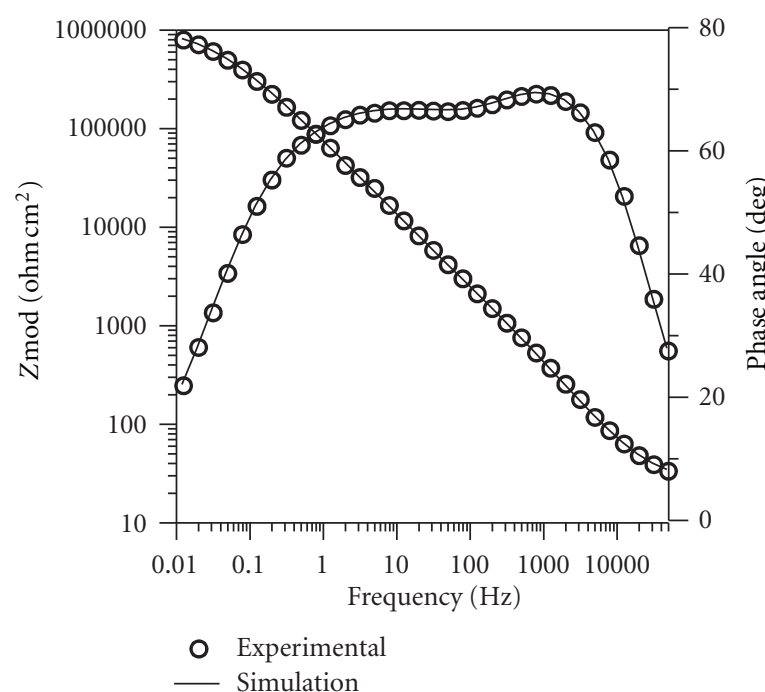

(a)

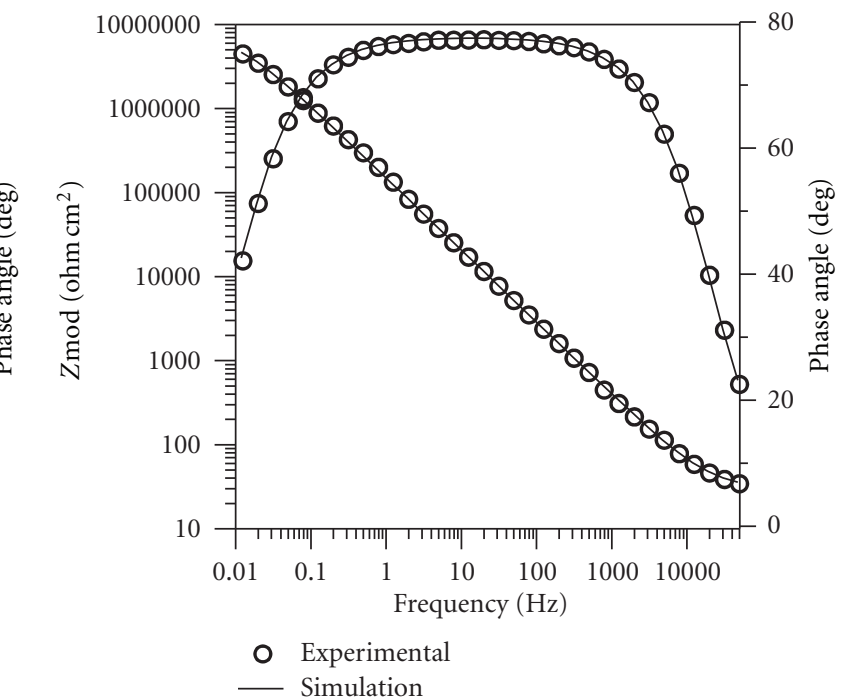

(b)

FIGURE 6: Bode plots for EIS data of NiTiNb alloy at (a) open circuit potential and (b) passive region.

with the resistance of the solution $\left(R_{\mathrm{sol}}\right)$ occurring between the sample and the reference electrode. The parameters $R_{2}$ and $Q_{2}$ describe the properties of the passive oxide layer formed on NiTi alloy. As the potential changed from OCP to $-30 \mathrm{mV}, R_{2}$ increased (from $0.2 \mathrm{M} \Omega \mathrm{cm}^{2}$ to $1.1 \mathrm{M} \Omega \mathrm{cm}^{2}$ ) and $Q_{2}$ decreased. These results seem to correspond to a slight thickening of the oxide layer. For the NiTi alloy polarized in physiological $0.9 \mathrm{wt} \% \mathrm{NaCl}$ solution at $200 \mathrm{mV}$ (dissolution region), within the low frequency range, an inductive behavior is observed. In this case the impedance data were fitted with the EC presented in Figure 5(c). For the $\mathrm{NiTi}$ alloys polarized in physiological $0.9 \mathrm{wt} \% \mathrm{NaCl}$ solution at $200 \mathrm{mV}$, the value of $R_{1}$, representing the charge transfer resistance, is quite low, about $100 \Omega \mathrm{cm}^{2}$. The $R_{3} L$ element is usually attributed to the relaxation of the corrosion products on the electrode surface [19]. In this case, the protectiveness of oxide layer is no longer present. In Figures 4(a)-4(c), the experimental data are shown as individual points, while the theoretical spectra resulting from the fits with ECs models are shown as lines.

All the resulting EIS parameters for the NiTi alloy in physiological $0.9 \mathrm{wt} \% \mathrm{NaCl}$ solution are given in Table 2 .

Figures 6(a)-6(b) show the Bode plot of NiTiNb alloys at $\mathrm{OCP}$ and the passive region $(300 \mathrm{mV})$.

The impedance spectra fitting for NiTiNb alloy at OCP in physiological $0.9 \mathrm{wt} \% \mathrm{NaCl}$ solution was carried out using the EC presented in Figure 5(a). Table 2 shows the results of the fitting. The EIS spectra for NiTiNb alloy polarized in physiological $0.9 \mathrm{wt} \% \mathrm{NaCl}$ solution at $300 \mathrm{mV}$ (passive region) could be analyzed in terms of the $\mathrm{EC}$ for a passive layer that is depicted in Figure 5(b).

The higher magnitude of impedance (around $10^{6} \Omega \mathrm{cm}^{2}$ ) was observed at the passive range of potential. Hence, the resistance of the formed layer in the passive region is higher than the resistance of the NiTiNb alloy at OCP, accounting for the higher corrosion resistance of the NiTiNb alloy. 
TABLE 2: Impedance parameters of NiTi and NiTiNb alloys in physiological $0.9 \mathrm{wt} \% \mathrm{NaCl}$ solution, at $37^{\circ} \mathrm{C}$.

\begin{tabular}{|c|c|c|c|c|c|c|c|c|c|}
\hline Sample & Imposed potential & $R_{1}\left(\mathrm{k} \Omega \mathrm{cm}^{2}\right)$ & $10^{5} Q_{1}\left(\mathrm{~S} / \mathrm{cm}^{2} s^{n}\right)$ & $n_{1}$ & $R_{2}\left(\mathrm{M} \Omega \mathrm{cm}^{2}\right)$ & $10^{5} Q_{2}\left(\mathrm{~S} / \mathrm{cm}^{2} s^{n}\right)$ & $n_{2}$ & $R_{3}\left(\Omega \mathrm{cm}^{2}\right)$ & $L\left(\mathrm{H} / \mathrm{cm}^{2}\right)$ \\
\hline \multirow{3}{*}{$\mathrm{NiTi}$} & $\mathrm{OCP}$ & 1.7 & 7.2 & 0.86 & 0.2 & 1.3 & 0.85 & - & - \\
\hline & Passive region & - & - & - & 1.1 & 0.8 & 0.86 & - & - \\
\hline & Dissolution region & 0.1 & 0.6 & 0.79 & - & - & - & 45 & 25 \\
\hline \multirow{2}{*}{ NiTiNb } & $\mathrm{OCP}$ & 21.5 & 2.3 & 0.88 & 0.6 & 1.1 & 0.86 & - & - \\
\hline & Passive region & - & - & - & 4.1 & 0.6 & 0.88 & - & - \\
\hline
\end{tabular}

Again, in Figures 6(a) and 6(b), the experimental data are shown as individual points, while the theoretical spectra resulting from the fits with ECs models are shown as lines.

The role of $\mathrm{Nb}$ plays as an alloying element is by increasing the resistance of NiTi alloy to pitting corrosion. NiTiNb alloy exhibited high corrosion resistance within the potential range used in the present study.

\section{Conclusions}

The addition of $\mathrm{Nb}$ to $\mathrm{NiTi}$ alloy facilitates passivation, produces the more stable passive layer by reducing anodic current density, and finally promotes the corrosion resistance.

The dynamic electrochemical impedance spectroscopic (DEIS) technique has been used to evaluate the corrosion resistance of the $\mathrm{NiTi}$ and $\mathrm{NiTiNb}$ alloys in physiological $0.9 \mathrm{wt} \% \mathrm{NaCl}$ solution.

The Bode plot for various regions, namely, OCP, passive region, and dissolution region was evaluated under the potentiodynamic condition, and each of these regions was discussed. For NiTi alloy a low and dangerous breakdown potential value (around $170 \mathrm{mV}$ ) may be recorded. The SEM images of corroded surfaces on NiTi alloy after anodic potentiodynamic polarization test confirm the pitting dissolution.

\section{Acknowledgments}

This paper was supported by the project PN-II-ID-PCE2011-3-0218, no. 266, and it was financed by the Romanian CNCS Program ID.

\section{References}

[1] M. Niinomi, "Mechanical properties of biomedical titanium alloys," Materials Science and Engineering A, vol. 243, no. 1-2, pp. 231-236, 1998.

[2] M. Geetha, A. K. Singh, R. Asokamani, and A. K. Gogia, "Ti based biomaterials, the ultimate choice for orthopaedic implants-a review," Progress in Materials Science, vol. 54, no. 3, pp. 397-425, 2009.

[3] D. Mareci, R. Chelariu, D. M. Gordin, M. Romas, D. Sutiman, and T. Gloriant, "Effect of Mo content on electrochemical behaviour of TiMo alloys for dental applications," Materials and Corrosion, vol. 61, no. 10, pp. 829-837, 2010.

[4] D. Mareci, R. Chelariu, I. Dan, D. M. Gordin, and T. Gloriant, "Corrosion behaviour of $\beta$-Ti20Mo alloy in artificial saliva," Journal of Materials Science, vol. 21, no. 11, pp. 2907-2913, 2010.
[5] M. Attarchi, M. Mazloumi, I. Behckam, and S. K. Sadrnezhaad, "EIS study of porous NiTi biomedical alloy in simulated body fluid," Materials and Corrosion, vol. 60, no. 11, pp. 871-875, 2009.

[6] M. Assad, A. V. Chernyshov, P. Jarzem et al., "Porous titaniumnickel for intervertebral fusion in a sheep model: part 2. Surface analysis and nickel release assessment," Journal of Biomedical Materials Research B, vol. 64, no. 2, pp. 121-129, 2003.

[7] O. Prymak, D. Bogdanski, M. Köller et al., "Morphological characterization and in vitro biocompatibility of a porous nickeltitanium alloy," Biomaterials, vol. 26, no. 29, pp. 5801-5807, 2005.

[8] C. C. Shih, S. J. Lin, Y. L. Chen et al., "The cytotoxicity of corrosion products of nitinol stent wire on cultured smooth muscle cells," Journal of Biomedical Materials Research, vol. 52, no. 2, pp. 395-403, 2000.

[9] T. Eliades and G. Eliades, "Orthodontic adhesives resins," in Orthodontic Materials. Scientific and Clinical Aspects, W. A. Brantley and T. Eliades, Eds., pp. 201-220, Thieme, New York, NY, USA, 2001.

[10] G. Rondelli, "Corrosion resistance tests on NiTi shape memory alloy," Biomaterials, vol. 17, no. 20, pp. 2003-2008, 1996.

[11] S. A. Shabalovskaya, "Surface, corrosion and biocompatibility aspects of Nitinol as an implant material," Bio-Medical Materials and Engineering, vol. 12, no. 1, pp. 69-109, 2002.

[12] P. Rocher, L. El Medawar, J. C. Hornez, M. Traisnel, J. Breme, and H. F. Hildebrand, "Biocorrosion and cytocompatibility assessment of NiTi shape memory alloys," Scripta Materialia, vol. 50, no. 2, pp. 255-260, 2004.

[13] G. Rondelli and B. Vicentini, "Effect of copper on the localized corrosion resistance of Ni-Ti shape memory alloy," Biomaterials, vol. 23, no. 3, pp. 639-644, 2002.

[14] R. L. W. Messer and L. C. Lucas, "Cytotoxicity of nickelchromium alloys: bulk alloys compared to multiple ion salt solutions," Dental Materials, vol. 16, no. 3, pp. 207-212, 2000.

[15] B. O’Brien, W. M. Carroll, and M. J. Kelly, "Passivation of nitinol wire for vascular implants-a demonstration of the benefits," Biomaterials, vol. 23, no. 8, pp. 1739-1748, 2002.

[16] Y. Fovet, J. Y. Gal, and F. Toumelin-Chemla, "Influence of $\mathrm{pH}$ and fluoride concentration on titanium passivating layer: stability of titanium dioxide," Talanta, vol. 53, no. 5, pp. 1053-1063, 2001.

[17] C. Li, Y. F. Zheng, and L. C. Zhao, "Electrochemical corrosion behavior of Ti-Ni-Nb alloy," Materials Science and Engineering A, vol. 438-440, pp. 504-508, 2006.

[18] D. Mareci, G. Ciurescu, R. Chelariu, I. Crefescu, and D. Sutiman, "In vitro corrosion study by electrochemical and surface analysis techniques of a TI50TA alloy for dental applications," Environmental Engineering and Management Journal, vol. 9, no. 1, pp. 81-87, 2010. 
[19] M. Meticos-Hukovic, Z. Pilic, R. Babic, and D. Omanovic, "Influence of alloying elements on the corrosion stability of CoCrMo implant alloy in Hank's solution," Acta Biomaterialia, vol. 2, no. 6, pp. 693-700, 2006. 

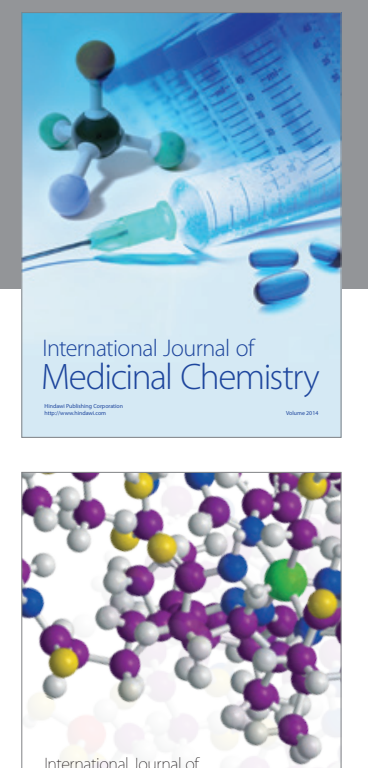

\section{Carbohydrate} Chemistry

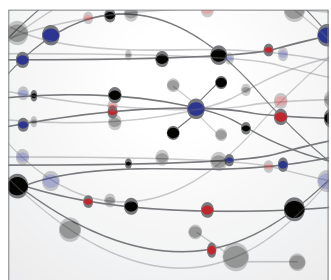

The Scientific World Journal
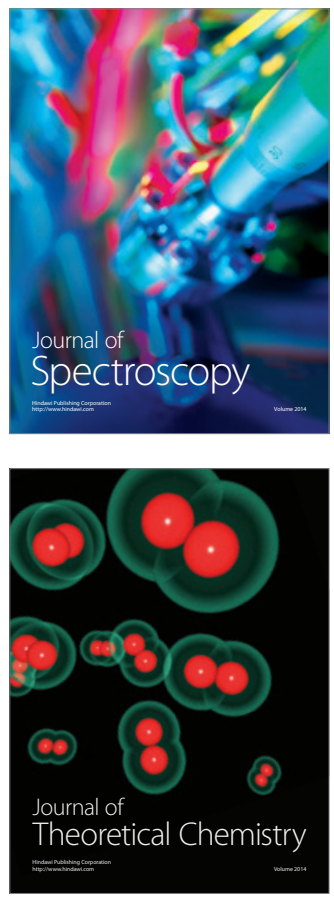
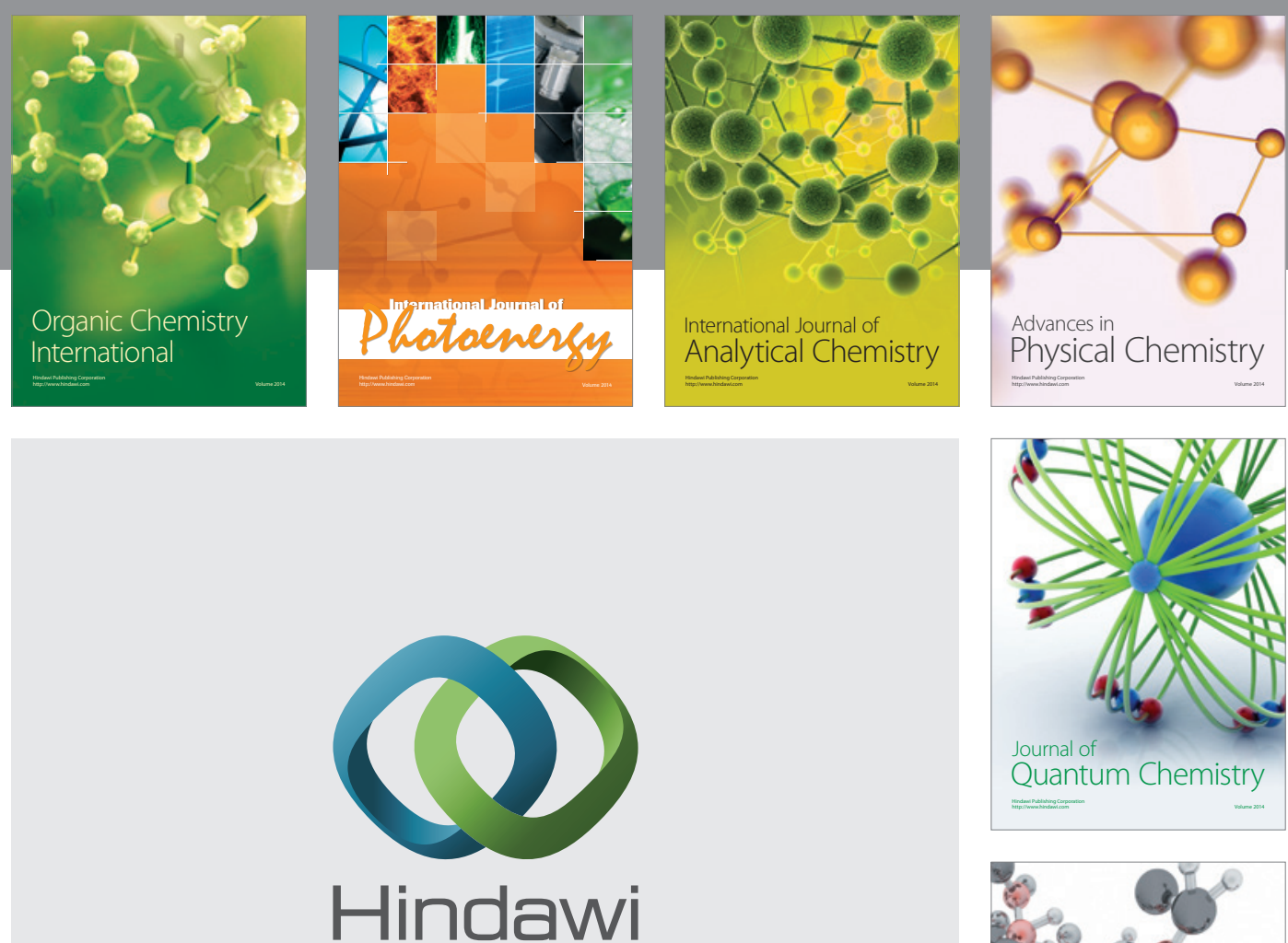

Submit your manuscripts at

http://www.hindawi.com

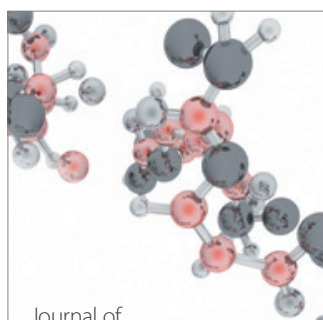

Analytical Methods

in Chemistry

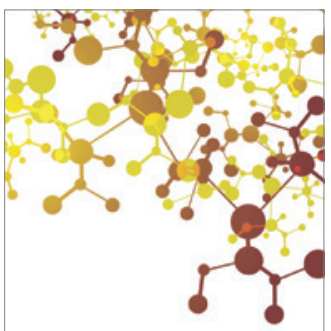

Journal of

Applied Chemistry

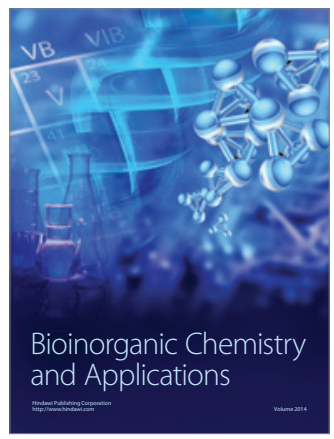

Inorganic Chemistry
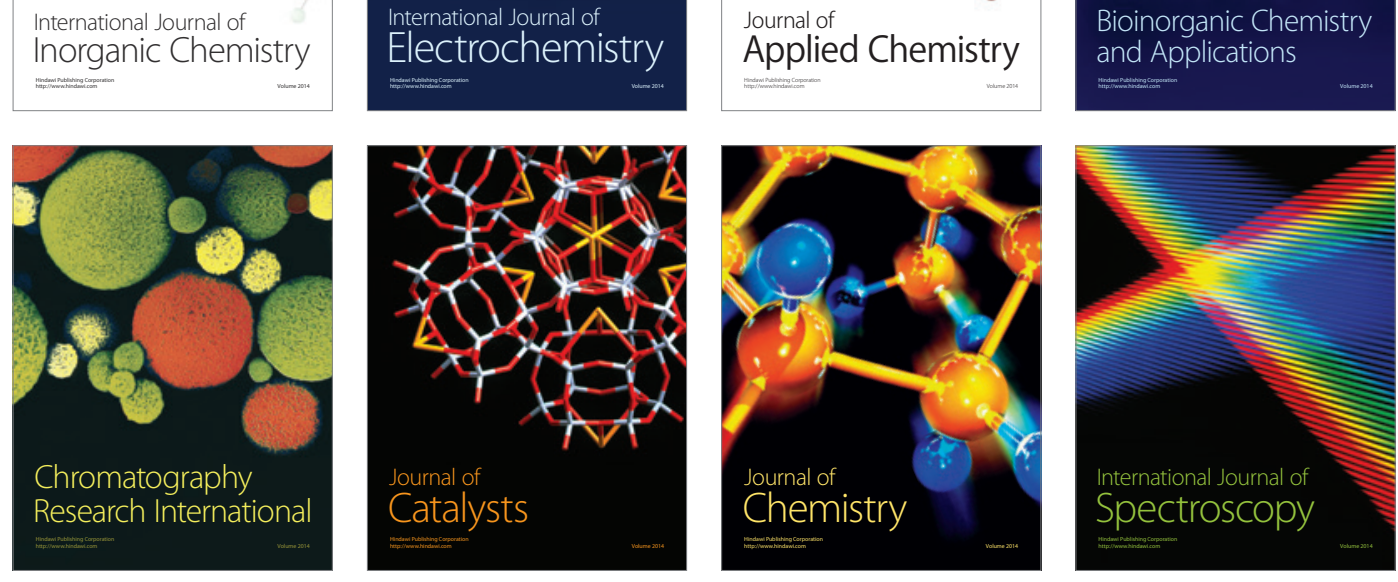